\title{
Suomen väestön uusiutumiskyvyn ja aviollisen hedelmällisyyden alueelli- sista eroavuuksista vuosina 1938-1939
}

Kirjoittanut Armas Nieminen.

Selviteltäessä kysymystä, miten »ka s v u k y ky in e n» tietty väestö on, suuriko »lisä än tymista i p u u s» eli »-ky ky» eli »vitaliteetti» sillä on, joudutaan pohtimaan väestön lisääntymisen erilaisia mittaamismahdollisu uksia. Tällainen tarkastelu tapahtuu tässä tutkielmassa saksalais-amerikkalaisen väestötieteilijän Robert $R$. Kuczynskin kehittämän metodin pohjalla ja hänen esittämäänsä terminologiaa käyttäen.

Aluksi voidaan todeta, että väestön lukumääräisen kehityksen kolmesta perustekijästä, s y n t y v y y de s tä, ku o levu u d e sta ja mu uttoliikkeestä, voidaan kahta ensiksimainittua pitää primäärisinä, koska välittömästi vain niiden vaikutuksesta riippuu koko ihmiskunnan määrä, kun sensijaan kolmas lueteltu tekijä vaikuttaa vain ihmisten oleskelupaikan määräytymiseen ja siten kartuttaa tai vähentää tietyn alueen väestöä toisten alueiden väestöjen kustannuksella tai eduksi. , Kun muuttoliikkeellä täten ei ole sitä biologista luonnetta, mikä on syntyvyydellä ja kuolevuudella, käsitetään tässäkin esityksessä mainitunlainen »vitaliteetti» vain syntymän ja kuoleman ilmiöiden resultanttina. 
Välittömimmin tarjoutuva syntyvyyden mittaamismenetelmä on tietyn ajanjakson (tavallisesti vuoden) kuluessa syntyneiden lasten lukumäärän vertaaminen väestön keskiväkilukuun (tavallisesti sen 1000 henkeä kohden eli \%o:eina) samana aikana. Täten saadaan tilastollinen käsite s y n ty ne is y y s ( $1 \mathrm{uk} \mathrm{u})$ (birth rate). Tämä on riittävän tarkka etenkin monia käytännöllisiä tarkoituksia varten, mutta syntyvyyden mittana syntyneisyys kuitenkin saattaa olla harhaanjohtava, jos siitä pyritään tekemään väestönkehitystä koskevia johtopäätöksiä tulevaisuuteen nähden, koska syntyneisyyden suuruuteen ei vaikuta ainoastaan väestön kulloinenkin hedelmällisyys (tilastollisessa, ei fysiologisessa merkityksessä), vaan myös menneisyydessä vallinneen siviilisäätyryhmityksen, hedelmällisyyssuhteiden ja kuolevuuden (sekä muuttoliikkeen) yhteisvaikutuksesta muodostunut väestön i k ä ra k e n$\mathrm{n}$ e, eri-ikäisten miesten ja naisten osuus koko väestöstä. Jos tässä näet on suhteellisen lukuisasti hedelmällisyysiässä olevia aviovaimoja, saattaa syntyneisyys kohota korkealle, vaikka heidän hedelmällisyytenșä ei ole suuri, ja päinvastoin. Kuten taulukosta 2 (siv. 56) havaitaan, oli siten - vain yhden esimerkin mainitaksemme - syntyneisyys vuosina 1938-39 Helsingissä suurempi kuin eräissä muissa Suomen kaupungeissa, vaikka hedelmällisyys, kuten samasta taulukosta bruttouusiutumisluvusta näkyy, pääkaupungissa oli kaikkein pienin maassamme.

Tarkempi syntyvyyden mitta saadaan vertaamalla vuoden kuluessa syntyneiden lasten määrää hedelmällisyysiässä olevien (tavallisesti 15-49-vuotiaiden) naisten lukuun. Täten saadaan ns. y leinen hedelmällisy ys ( 1 uku) (general fertility rate). Tähänkin nähden pitää kuitenkin — vaikkakin vähäisemmässä määrässä - paikkansa sama huomautus, mikä esitettiin syntyneisyyden suhteen. Jos näet 25-30-vuotiaat naiset muodostavat suhteellisen suuren osan väestöstä, saattaa yleinen hedelmällisyys olla korkea, vaikka hedelmällisyys missään ikäluokassa ei sitä olekaan. Tämän vuoksi on otettu käytäntöön ns. e rikois hedelmällisyysluvut (specific fertility rates), on ryhdytty vertaamaan kunkin ikäluokan naisten vuoden kuluessa synnyttämien lasten määrää heidän omaan lukumääräänsä. Täten saa- 
tavat 35 lukua ilmaisevat yleistä hedelmällisyyttä paljon tarkemmin syntyvyyden »voimakkuuden», toisin sanoen niitä käyttäen saadaan ikärakenteen vaikutus eliminoiduksi. Kuitenkin koituu vain merkityksettömäksi katsottava virhe, vaikka laskelmia ei suoritetakaan kaikkiin 35 ikäluokkaan nähden, vaan tyydytään 5vuotisikäryhmiin (15-19-vuotiaat, 20 -24-vuotiaat ... 45-49-vuotiaat naiset). Sitäpaitsi tuo tarkempi menettelytapa ei sovellu käytettäväksi pieneen väestöön, koska satunnaisuudet tällöin pääsevät vaikuttamaan yhden ikäluokan puitteissa. Sensijaan yleinen hedelmällisyysluku sisältää kokonaan toista suuruusluokkaa olevan epätarkkuuden. ${ }^{2}$

Erikoishedelmällisyysluvut voidaan tiivistää yhdeksi tilastoluvuksi laskemalla ne yhteen tai, jos laskelmat suoritetaan 5 -vuotisikäryhmien perusteella, kertomalla ennen yhteen laskemista kukin erikoishedelmällisyysluku 5:llä. Siten saadaan ns. k okon a ishedelmällisy y s ( 1 u ku) (total fertility rate). Tämä osoittaa, montako lasta olemassa olevien hedelmällisyyssuhteiden vallitessa syntyisi esim. 1000:1le hedelmällisyysiän saavuttaneelle naiselle, ellei heistä kukaan kuolisi ennen tämän ajan päättymistä, joten naisten määrä kaikissa ikäluokissa pysyisi entisellään. Tuo luku ilmaisee samalla myös, montako lasta vastasyntynyt tyttölapsi keskimäärin tulisi synnyttämään elinaikanaan, jos hän eläisi hedelmällisyyskautensa loppuun. Kun vastasyntyneiden sukupuoliryhmitykseen nojautuen sitten lasketaan, montako näistä lapsista olisi tyttöjä, saadaan bruttou usiutumis- eli -reproduktioluku (gross reproduction rate). Tämä luku siis ilmaisee, missä määrin väestö olemassa olevien hedelmällisyyssuhteiden vallitessa uusiutuisi, jos kuolleisuuden vaikutusta ei lainkaan otettaisi huomioon.

Koska uusi sukupolvi syntyy (normaalitapauksessa) avioliitossa ja koska yhteiskunta pyrkii siihen, että näin yhä suuremmassa määrässä tapahtuisi, herättävät väestön lisääntymisen kannalta erityistä mielenkiintoa aviovaimoihin kohdistuvat hedelmällisyyslaskelmat, a viollis en he delmällis y y den mittaaminen. Tästähän voidaan nähdä, suurenko panoksen eri avioliittoryhmät 
asettavat väestön ylläpitämiseen ja nousevan sukupolven synnyttämiseen ja kasvattamiseen.

Kun kuolevuudenkin vaikutus otetaan huomioon väestön kehityksessä, tarjoutuu yleisimpänä käsitteenä käytettäväksi ns. k u o 1le is u u s ( l u k u), kuolleiden määrä keskiväkiluvun 1000 henkeä kohden. Tämä on kuitenkin samalla tavoin epätarkka kuolevuuden mitta, kuin syntyneisyys on hedelmällisyyden, sillä jos kaikkein nuorimmat ja vanhat ikäluokat käsittävät väestöstä suhteellisen pienen osan, mutta työkykyiset ikäluokat sensijaan suuren, saattaa kuolleisuus olla pieni siitä huolimatta, että (kuolevuustauluissa ilmaistu) $\mathrm{kuolem}$ a n va a ra kussakin ikäluokassa eli kussakin ikäluokassa kuolleiden määrä saman ikäluokan koko väestöön verrattuna on suhteellisen korkea. Tästä myös johtuu, että syntyneisyyden enemmyys eli ns. luonnollinen väenlisäys, so. syntyneisyyden ja kuolleisuuden erotus, ei ole tarkka lisääntyvyyden mitta. Siitä, että esim. jonkin kaupungin väestössä syntyneisyys keskimäärin vuosittain olisi n. 750 henkeä suurempi kuin kuolleísuus, kuten keskimäärin tutkimusvuosina oli laita Helsingissä ${ }^{3}$, ei siis voi tehdä sitä johtopäätöstä, että kaupungin väestö pystyisi edes uusiutumaan, jos muuttoliike pysyväisesti lakkaisi. Ikärakenteen ollessa sellainen, kuin äsken mainittiin, saattaa syntyneisyysluku olla suuri ja kuolleisuusluku pieni siitä huolimatta, että kokonaishedelmällisyys on pieni ja kuolemanvaara kussakin ikäluokassa suuri. Toisin sanoen nykyhetken syntyneisyyden enemmyyttä ilmaisevaan lukuun vaikuttaa menneisyyden panos, muuttoliikkeestä puhumattakaan, joka erityisesti kaupunkeihin tuo runsaasti juuri hedelmällisyysiässä olevaa ihmisainesta.

Edellä mainituista syistä aiheutuva tietynlainen ikärakenne ja sen vaikutus syntyneisyyteen voidaan kuitenkin eliminoida tutkimalla väestön uusiutumiskykyä, kun perustaksi asetetaan tietyt hedelmällisyys- ja kuolevuussuhteet. Kysymys tulee tällöin kuulumaan, monelleko tytölle keskimäärin vastasyntynyt tyttölapsi elinaikanaan tulee antamaan elämän. Täten saadaan n et tou usiutumis- eli -reproduktioluku (net reproduction rate). Jos tämä luku on $=1,0$, korvaisi uusi sukupolvi, 
jos uusiutumistekijät jäisivät ennalleen ja jos muuttoliikettä ei lainkaan oteta huomioon, suuruudeltaan ajan mittaan täydellisesti entisen, mutta väestö ei kasvaisi. Jos tuo luku taas on suurempi kuin 1,0, olisi väestön kasvu turvattu, mutta jos se jää tuon rajan alapuolelle, tulisi mainituilla edellytyksillä väestön kasvu aikanaan lakkaamaan ja vaihtumaan vähenemiseksi. Jos nettouusiutumisluku täten olisi pysyväisèsti 1,5 , olisi seuraava sukupolvi aina $50 \%$ suurempi kuin edellinen, mutta luvun jäädessä 7,5:een vain puolet edellisestä.

Väestön uusiutumiskyvyn tutkimuksia on Suomessa jonkin verran suoritettu koko maan maaseudun ja kaupunkien (yhtenä ryhmänä) osalta, mutta ei eri kaupunkien eikä eri läänien keskeistä systemaattista vertailua. ${ }^{4}$ Aviollisen hedelmällisyyden kehityssuuntaa sen sijaan on monipuolisemmin valaistu. ${ }^{5}$

\section{Tutkimuksen tarkoitus ja laskemisperusteet.}

Nyt käsillä olevan tutkimuksen tarkoituksena on edellä selvitettyä metodia käyttäen - on olemassa muitakin menettelytapoja - valaista väestön »kasvukyvyn» alueellista eroavuutta, seuraavassa esitetyistä syistä vuosina 1938-1939. Kun kaupunkien ja maaseudun väestöolot ja väestönkehitys monessa suhteessa eroavat toisistaan, on laskelmat suoritettu erikseen $\mathrm{kunk}$ in läänin kaupunkien (yhtenä ryhmänä) ja ma aseudun osalta. Koska kaupungit kuitenkin ovat keskenään hyvin heterogeenisia suuruutensa ja elämänsä yleisen luonteenkin puolesta ja koska esim. käsite »Uudenmaan läänin kaupunki» täten on hyvin suuressa määrässä todellisuudelle vieras abstraktio, on kutakin kaupunkia tarkásteltu erikseen. Samasta syystä on, koska kauppalat, taajaväkiset yhdyskunnat ja muut maaseudun asutuskeskukset sisältyvät väestötilastossa maaseutuun, vielä erikseen pyritty käsittelemään eri läänien varsinaisia ma ta louskuntia. Kun tässä suhteessa ei ole voitu ryhtyä syvällisempiin tutkimuksiin - ensimmäisen todellisen väestölaskennan suorittaminen tulee suomaan tällaisille entistä parem- 
mat edellytykset -, on maatalouskuntia edustamaan kunkin läänin puitteissa valittu muutamia seuraavassa esitettäviä poisjättöjä ja lisäyksiä lukuunottamatta samat kunnat, joissa vuonna 1937 toimitettiin maaseudun asunto-oloja koskeva valtion virallinen tutkimus. Tällöinhän nimittäin jätettiin yleensä pois teollisuuskunnat ja rajoituttiin varsinaisiin maatalouskuntiin. ${ }^{6}$

Maatalouskuntien osalta tutkimus käsittää seuraavat 59 maalaiskuntaa. Uudenmaan läänissä 5 kuntaa: Tammisaaren mlk., Degerby, Nurmijärvi, Lappträsk ja Jaala; Turun ja Porin läänissä 11 kuntaa: Lokalahti, Mietoinen, Piikkiö, Vestanfjärd, Muurla, Angelniemi, Pomarkku, Luvia, Jämijärvi, Suoniemi ja Keikyä; Ahvenanmaan läänissä 3 kuntaa: Jomala, Finström ja Sund; Hämeen läänissä 6 kuntaa: Humppila, Viiala, Juupajoki, Sahalahti, Tyrväntö ja Koski; Viipurin läänissä 7 kuntaa: Pyhtää, Ylämaa, Suomenniemi, Joutseno, Kanneljärvi, Kaukola ja Simpele; Mikkelin läänissä 4 kuntaa: Hartola, Anttola, Jäppilä ja Enonkoski; Kuopion läänissä 5 kuntaa: Rautalampi, Tervo, Muuruvesi, Pyhäselkä ja Rautavaara; Vaasan läänissä 8 kuntaa: Siipyy, Bergö, Ylihärmä, Ahtävä, Ullava, Lehtimäki, Toivakka ja Konginkangas; Oulun läänissä 6 kuntaa: Rautio, Siikajoki, Pulkkila, Hyrynsalmi, Ii ja Taivalkoski; sekä Lapin läänissä 4 kuntaa: Karunki, Tervola, Turtola ja Sodankylä. Asuntotutkimukseen sisältyneistä kunnista tästä luettelosta puuttuvat Viipurin läänissä Soanlahti, koska se vuoden $1940 \mathrm{~ns}$. kymmenvuotistilastossa esiintyi yhdessä Suistamon kanssa, sekä Vaasan läänissä Seinäjoki asutuskeskuksena. Toiselta puolen tässä tutkimuksessa on lisäksi mukaan otettu Ahvenanmaan ja Lapin lääneistä muutamia kuntia, jotta tutkittava väestö ei jäisi liian pieneksi ja siten edustavuudeltaan sattumanvaraiseksi. Ensiksi mainitun läänin kuntia oli asuntotutkimuksessa nimittäin vain Sund ja Lapin läänin kuntia Karunki.

Jotta väestön uusiutumista ja aviollista hedelmällisyyttä koskevia laskelmia voitaisiin suorittaa, on tarpeen tuntea naispuolisen väestön jakaantuminen iän ja siviilisäädyn mukaan. Näitä seikkoja koskevia tietoja saadaan Suomen väestötilastossa kuitenkin vain nollalla päättyvien vuosien lopussa ns. kymmenvuotistauluston teon yhteydessä. Muilta ajoilta ei mainittua tietoa voida maan 
eri alueilta saada laskemallakaan käyttäen hyväksi syntyneiden lukuja ja kuolleiden ikäryhmitystä, koska muuttaneiden ikäryhmitys ei ole selvillä. Niin ollen tutkimus on kohdistettu v u osi i n 1938-1939, jotka ovat lähellä kymmenvuotistauluston valmistumisaikaa, mutta jolloin sodan aiheuttama epänormaalisuus syntyvyydessä ei vielä tuntunut. Kaikki tässä kirjoituksessa ja sen taulukoissa esitetyt laskelmat, ellei toisin mainita, koskevat mainittuja vuosia.

Erikoishedelmällisyysluvut on tässä tutkimuksessa laskettu siten, että ensiksi on elävänä syntyneet jaettu ryhmiin äidin iän mukaan samassa suhteessa, kuin syntyneet jakaantuivat ko. läänin kaikissa kaupungeissa tai maaseudulla näihin ryhmiin. ${ }^{7}$ Tämä ei kuitenkaan johda täysin oikeisiin tuloksiin eri kaupunkien ja maatalouskuntien osalta. Tarkempi menettely yksityisiä kaupunki- ja maalaiskuntia tarkasteltaessa olisi ollut se, että kunkin kunnan kohdalla olisi syntyneet jaoiteltu äidin iän mukaan, mutta tämä olisi ollut suoritettava tilastollisen päätoimiston alkuaineistosta ja olisi siten vaatinut suurta lisätyötä. Naisten ja aviovaimojen määrä eri viisivuotisikäryhmissä tutkimusvuosina taas on saatu siten, että vuoden 1940 päättyessä vallinneen läsnäolevan väestön vastaavia lukuja ${ }^{8}$ on muunnettu samassa suhteessa, kuin ko. alueen keskiväkiluku vv. 1938-1939 suhtautui väkilukuun vuoden 1940 päättyessä. Keskiväkiluku vuosina 1938-1939 on laskettu vuosien 1937-1939 ns. »lasketūn väkiluvun» nojalla, sen jälkeen kun tätä on korjattu suhteellisesti vuoden 1940 päättyessä vallinneen »virallisen» ja »lasketun» väkiluvun erotuksen perusteella. ${ }^{9}$ Epätarkkuutta tässä tutkimuksessa siis aiheutuu siitä seikasta, että ei ole voitu ottaa huomioon suorastaan tutkimusvuosien ikä- ja siviilisäätyryhmitystä, vaan se on täytynyt laskea hiukan myöhemmän ajankohdan nojalla. Tämän tekijän vaikutus on aviolliseen hedelmällisyyteen nähden suurempi kuin uusiutumislukuihin.

Kuolevuudessa ei tässä tutkimuksessa ole voitu ottaa huomioon eri läänien kesken vallitsevia eroavuuksia, koska tämä olisi vaatinut eri kuolevuustaulujen laskemisen kutakin lääniä varten. Tutkimuksessa on käytetty vuosilta 1936-1940 laskettuja 
koko maan läsnäolevan naíspuolisen väestön kuolemanvaaralukuja, mutta ne on muunnettu samassa suhteessa kuin kaupunkien (maaseudun) vastaavat luvut vv. 1941-1945 erosivat koko maan läsnäolevan väestön vastaavista luvuista näinä vuosina. ${ }^{10}$ Täten on voitu ottaa huomioon kaupunkien ja maaseudun kuolevuussuhteissa vallitseva, mutta ei sen sijaan maan eri osissa vallitsevaa eroavuutta.

Nettouusiutumislukulaskelmat on suoritettu »siviilikuolleisuuteen» perustuen, joten sodassa kaatuneet eivät niihin vaikuta. Elävänä syntyneiden tyttöjen osuutta kaikista elävänä syntyneistä osoittava suhdeluku on laskettu erikseen kaupungeissa ja erikseen maaseudulla vuosina 1936-1940 syntyneistä.

\section{Väestön uusiutumiskyky.}

Tutkimuksen paljastamat väestön uusiutumiskykyä koskevat tulokset on esitetty kuviossa 1 sekä taulukoissa 1 ja 2. Tärkein niistä tehtävissä oleva huomio on, että uusiutuminen ja niin ollen myös väestön »kasvukyky» voimistui kaksinkertaiseksi siirryttäessä maan etelärannikolta pohjois-Suomeen. Turun ja Porin läänin maaseudulla uusiutuminen kuitenkin oli voimakkaampaa kuin Hämeen läänissä, Vaasan läänissä taas heikompaa kuin Kuopion läänissä. Eri läänien maaseudut sijoittuivat näin seuraavaan järjestykseen väestön uusiutumiseen nähden: Oulun ja Lapin läänit olivat johdossa kaukana muista edellä, sitten seurasivat Kuopion, Mikkelin, Vaasan, Viipurin, Turun ja Porin, Hämeen, Ahvenanmaan ja Uudenmaan läänit. Jos tarkastellaan, missä määrin tähän luetteloon verraten ilmenee eroavuutta, kun on kysymys eri läänien maaseutujen järjestyksestä syntyneisyyden enemmyyden suhteen, todetaan, että viimeksimainittu Ahvenanmaan maaseudulla oli verrattomasti pienin ja että se Mikkelin ja Vaasan lääneissä jäi alhaisemmaksi kuin Viipurin läänissä. Hämeen, Ahvenanmaan ja Uudenmaan läänien maaseudulla ei väestö enää ollut lainkaan uusiutumiskykyistä nettouusiutumislukujen jäädessä alle 1,0:n, ja muutkin eteläiset läänit, Turun ja Porin sekä Vii- 
purin lääni, olivat lähellä tätä rajảkohtaa. Sen sijaan Lapin läänin maatalouskunnissa, joissa nettouusiutumisluku oli suurin, väestö - ellei muuttoliikettä lainkaan olisi - melkein kaksinkertaistuisi jokaisen sukupolven kuluessa. Hämeen ja Viipurin läänin maatalouskunnissakin nettouusiutumisluvut jäivät selvästi ja Uudenmaan läänissä täpärästi 1,0:n alapuolelle. Hämeen ja Viipurin läänejä lukuunottamatta nettouusiutumisluku oli maatalouskunnissa hiukan suurempi tai yhtä suuri kuin läänien koko maaseudulla. Etsittäessä syytä siihen, että mainittujen läänien »maatalouskuntien» uusiutumisluvut jäivät huomattavasti pienemmiksi kuin samojen läänien koko maaseudun vastaavat luvut, on todettava, että Hämeen läänin tutkimuskunnista Viiala ja Viipurin läänin kunnista Joutseno olivat itse asiassa huomattavia teollisuuskuntia ja muihin saman läänin »maatalouskuntiin» verrattuna lisäksi suuria kuntia, joten niiden väestö tuli paljon »painamaan» tässä tutkimuksessa.

Kaupunkien väestön uusiutumiskykyä - niiden ikärakenteelle kun on ominaista työkykyisten ikäluokkien vallitsevuus - ei tämän tutkimuksen valossa lainkaan voi päätellä syntyneisyyden enemmyydestä. Vaikka kaikissa muissa kaupungeissa paitsi Uudessakaupungissa ja Naantalissa oli syntyneiden enemmyyttä (taulukko 2), oli vain Kemin nettouusiutumisluku 1.0:aa suurempi, mikä osoittaa, että kaikkien muiden kaupunkien paitsi Kemin väestön lisääntyminen oli kokonaan hedelmällisyysiässä olevien ikäluokkien suhteellisen runsauden ja kaupunkiin muuton varassa. Keskimääräisesti laskien oli kaupunkien väestön uusiutumiskyky vain noin puolet vastaavasta maaseudun luvusta. Pienin, 0.484, oli Helsingin nettouusiutumislukú. Oman lisääntymisvoimapsa varaan jatkuvasti jätettynä Helsingin väestö siis vuosien 1938-39 hedelmällisyysssuhteiden vallitessa jokaisessa sukupolvessa kutistuisi aina vähemmän kuin puoleen entisestään. Myös yksityisiin kaupunkeihin nähden havaitsee saman seikan kuin maaseutuun, että uusiutuminen pohjoisempana yleensä oli voimakkaampaa, mutta tendenssi ei tässä suhteessa ollut yhtä selvä 


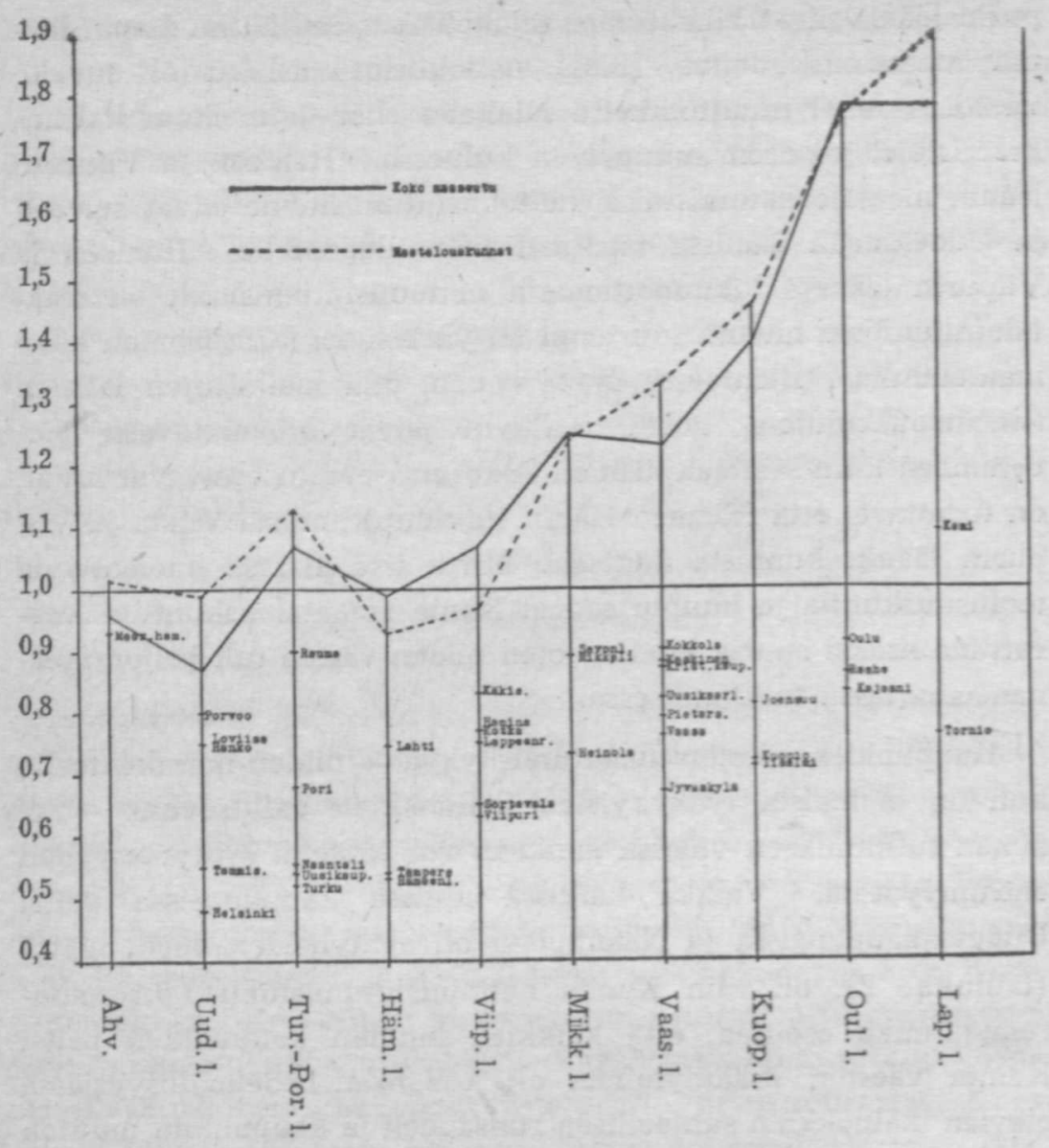

Kuvio 1. Nettoursiutumisluku vv. 1938-39.

kuin maaseutuun nähden. Suuret kaupungit Helsinki, Turku, Tampere, Viipuri, Kuopio ja Vaasa, joissa uusiutuminen oli suhteellisen heikkoa, aiheuttivat näiden läänien kaupunkien yhteisluvussa laskua. Mutta hyvin heikkoa uusiutumista osoittivat myös eräät pienet kaupungit (Hämeenlinna, Uusikaupunki, Tammisaari ja Naantali). 
Edellä esitetty tarkastelu perustuu kuitenkin, kuten jo on huomautettu, siihen edellytykseen, että kuolemanvaara kussakin ikäluokassa toisaalta maaseudulla ja toisaalta kaupungeissa olisi ollut tasainen kautta koko maan, joten tässä selvittelyssä ei ilmennyt maan eri osissa mahdollisesti vallitsevien kuolevuuden eroavuuksien vaikutus nettouusiutumislukuun. Siihen, että tämä seikka ei ainakaan Helsinkiin nähden ole johtanut erehdyttävään tulokseen, viittaa se, että Helsingin omien (v:ilta 1941-45 laadittujen) kuolevuustaulujen perusteella laskettu nettouusiutumisluku vuodelta 1942 oli 0.547 eli $11.3 \%$ suurempi kuin tässä tutkimuksessa saatu luku, kun vastaavasti syntyneisyys mainittuna vuonna oli 11.1 \% suurempi kuin keskimäärin vuosina $1938-39 .{ }^{11}$ Sikäli kuin kuolemanvaara pohjoisissa lääneissä olisi ollut suurempi kuin eteläisissä, eivät eroavuudet nettouusiutumisluvuissakaan olisi nousseet niin suuriksi, kuin mihin tämä tutkimus viittaa. Siitä, että tässä tutkimuksessa kuolevuuden mahdollinen erilaisuus ei päässyt ilmenemään, myös johtuu, että toisaalta kaupunkien ja toisaalta maaseudun bruttouusiutumislukujen keskinäinen vertailu muodostuu samanlaiseksi kuin nettouusiutumislukujenkin. Siinäkääan tapauksessa, että kaikki naiset eläisivät 50-vuotiaiksi, ei siis muiden läänien kuin Lapin, Oulun ja Mikkelin läänien kaupungeilla sekä Maarianhaminalla olisi uusiutumiskykyä. Siitä, että kuolevuus maaseudulla oli suurempi kuin kaupungeissa, johtuu, että maaseudun nettouusiutumisluku bruttouusiutumislukuun verrattuna oli vähän pienempi kuin kaupunkien uusiutumislukujen vastaavanlaisessa vertailussa.

\section{Aviollinen hedelmällisyys.}

Ne tekijät, jotka määräävät uusiutumisen voimakkuuden, ovat - paitsi kuolevuutta - aviollinen ja avioton hedelmällisyys kussakin ikäluokassa sekä hedelmällisyysiässä olevien naisten siviilisäätyryhmitys. Koska avioton hedelmällisyys kuitenkin on hyvin vähäistä aviolliseen verrattuna, on siis väestön uusiutumiselle 
ratkaisevaa, suuriko osa hedelmällisyysiässä olevista naisista on naimisissa ja suuriko heidän hedelmällisyytensä on.

Aviollinen hedelmällisyys, so. syntyneiden aviolasten luku verrattuna 15-49-vuotiaiden aviovaimojen määrään, on esitetty kuviossa 2 sekä taulukoissa 3 (alhaalla) ja 4 . Verrattaessa toisiinsa kuvioita 1 ja 2 havaitaan, että sekä kaupunkien että maaseudun nettouusiutumisluvun ja aviollisen hedelmällisyyden »käyrien» kuiku oli hyvin samanlainen, mikä siis osoittaa, että juuri aviollinen hedelmällisyys ratkaisevasti määräsi väestön uusiutumiskyvyn suuruuden. Edellä esitetty eri läänien maaseutujen järjestys väestön uusiutumiskykyyn nähden piti siis myös paikkansa aviollisesta hedelmällisyydestä. Näin oli asianlaita myös eri läänien kaupunkeihin nähden (yhtenä ryhmänä), paitsi että Lapin läänin kaupunkien aviollinen hedelmällisyys oli pienempi kuin Oulun läänin, kun sen sijaan uusiutumislukuihin nähden asianlaita oli päinvastainen. Mutta Lapin läänin kaupungeissa olikin hedelmällisyysiässä olevia aviovaimoja 14.2 \% keskiväkiluvusta, kun vastaava luku Oulun läänin kaupungeissa oli vain $13.0 \%$. Samaten oli aviollinen hedelmällisyys Lapin läänin maaseudulla pienempi kuin Oulun läänin maaseudulla.

Yksityisiin kaupunkeihin nähden sen sijaan ilmeni suurempia eroavuuksia, mikä osoittaa, että kaupungeissa uusiutumiseen ei niin yksinomaisesti kuin maaseudulla vaikuttanut aviollinen hedelmällisyys, vaan myös siviilisääty- ja ikäryhmitys. Aviollisessa hedelmällisyydessä olivat johdossa pienet etelän kaupungit Maarianhamina, jonka ansiosta »kaupunkien» luyut Ahvenanmaan kohdalla kautta koko tämän tutkimuksen kohosivat erinomaisen korkealle, ja Porvoo. Vain näissä kahdessa kaupungissa aviollinen hedelmällisyys oli suurempi kuin ko. läänin maaseudulla. Näiden kaupunkien jälkeen tulivat sitten Uusikaarlepyy sekä Pohjolan kaupungit Rahe, Oulu ja Tornio. Että viimeksimainittu kaupunki suuresta aviollisesta hedelmällisyydestään huolimatta jäi takapajulle nettouusiutumislukuunsa nähden, johtui mm. siitä, että siellä hedelmällisyysiässä olevien aviovaimojen suhteellista osuutta koko väestöstä osoittava luku (9.7\%) oli pienempi kuin missään muussa Suomen kaupungissa Uuttakaarlepyytä (8.4 \%) 


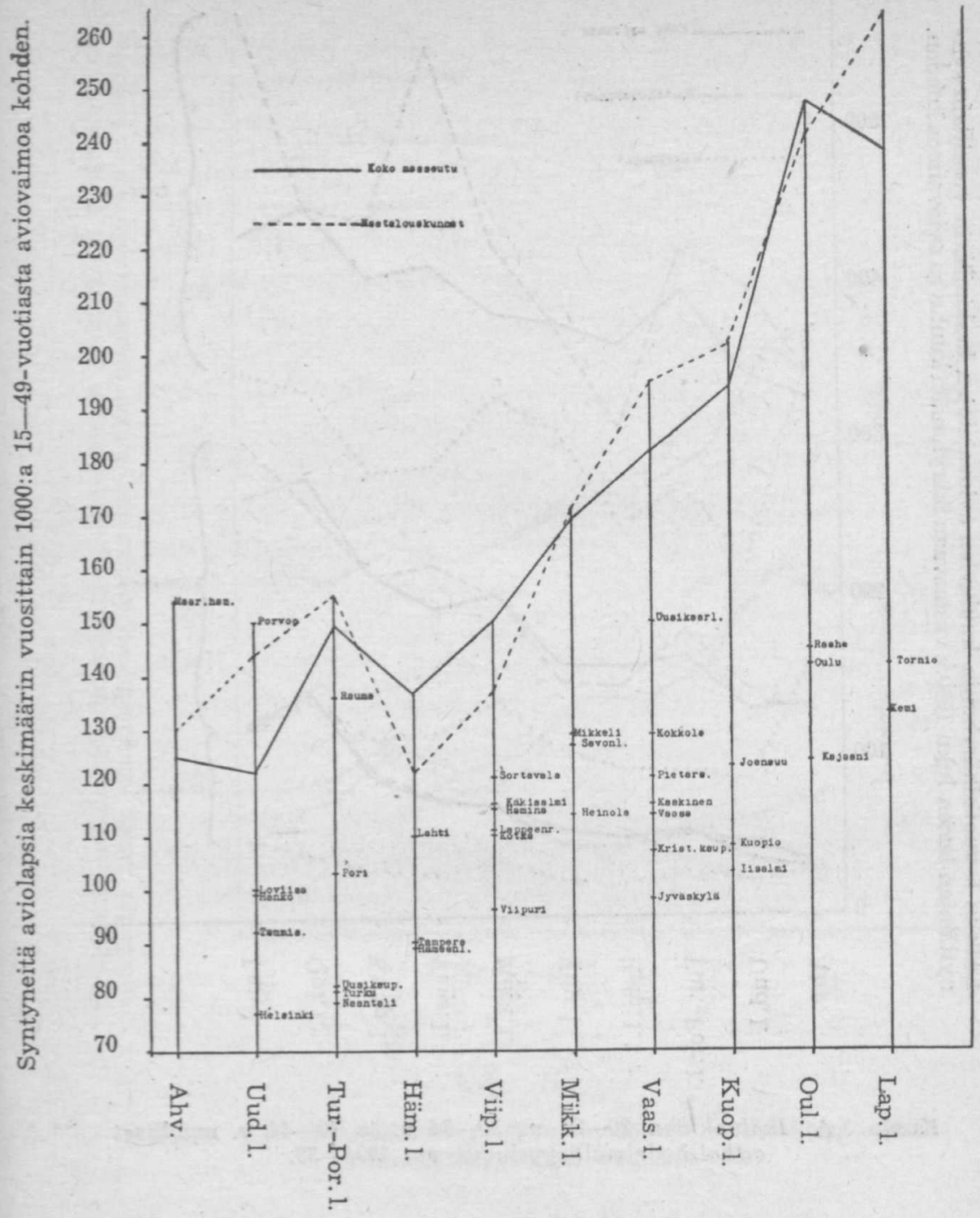

Kuvio 2. Aviollinen hedelmällisyys vv. 1938-39.

ja Raahea (9.6\%) lukuunottamatta ${ }^{12}$, jotka, kuten jo mainittiin, aviollisen hedelmällisyyden suhteen myös olivat aivan kärjessä, mutta uusiutumislukuunsa nähden vaatimattomammalla sijalla. 


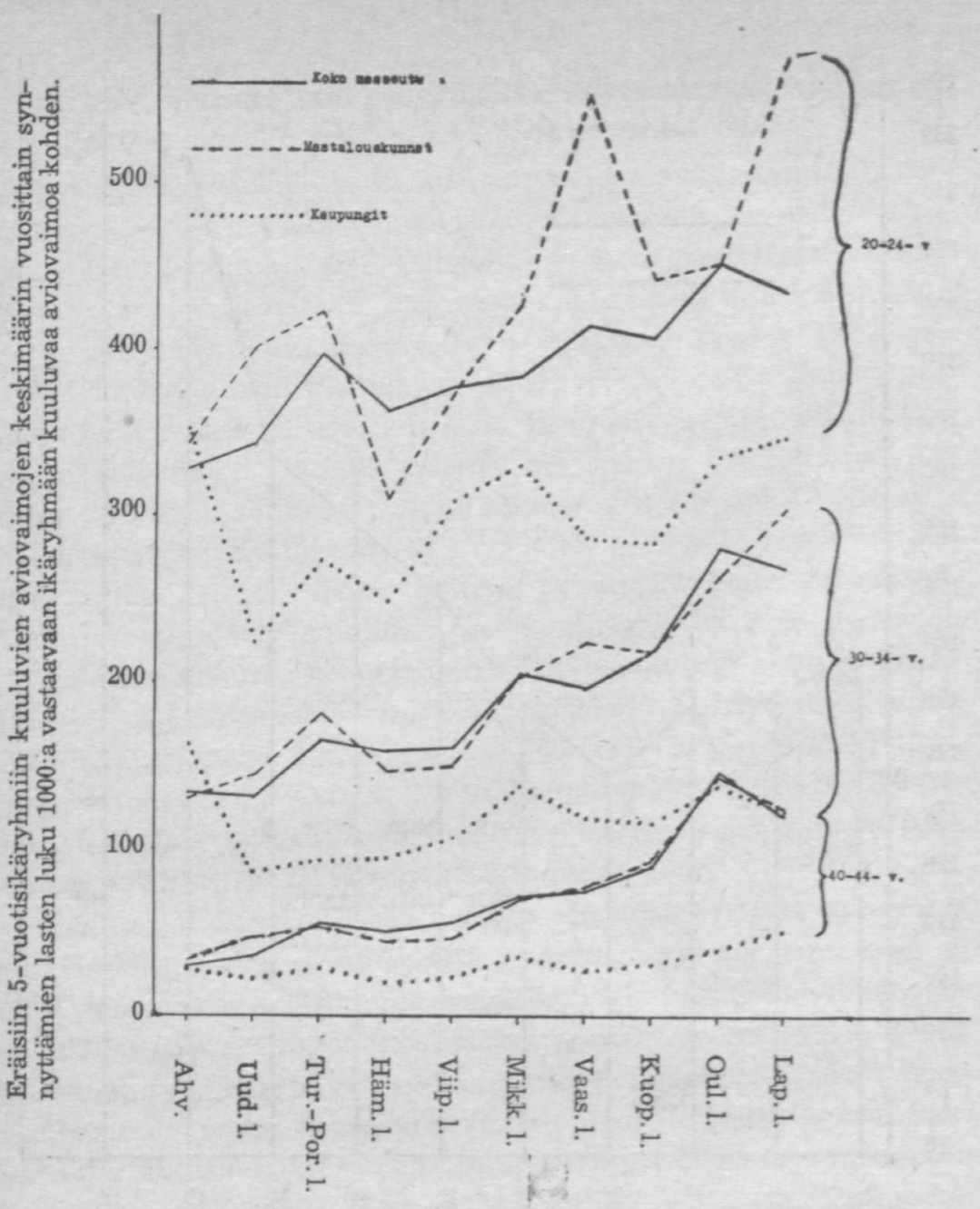

Kuvio 3 A. Ikäluokkien $20-24$ v., $30-34$ v. ja $40-44$ v. aviolliset erikoishedelmällisyysluvut vv. $1938-39$.

Kemissäkin oli varsin korkea aviollinen hedelmällisyys, vaikka se olikin menettänyt sen johtoasemansa, mikä sillä kaupunkien joukossa oli uusiutumislukuun nähden. Hedelmällisyysiässä olevien aviovaimojen oșuus koko väestöstä olikin Kemissä hiukan suurempi kuin kaupungeissa keskimäärin. Suuret kaupungit Hel- 


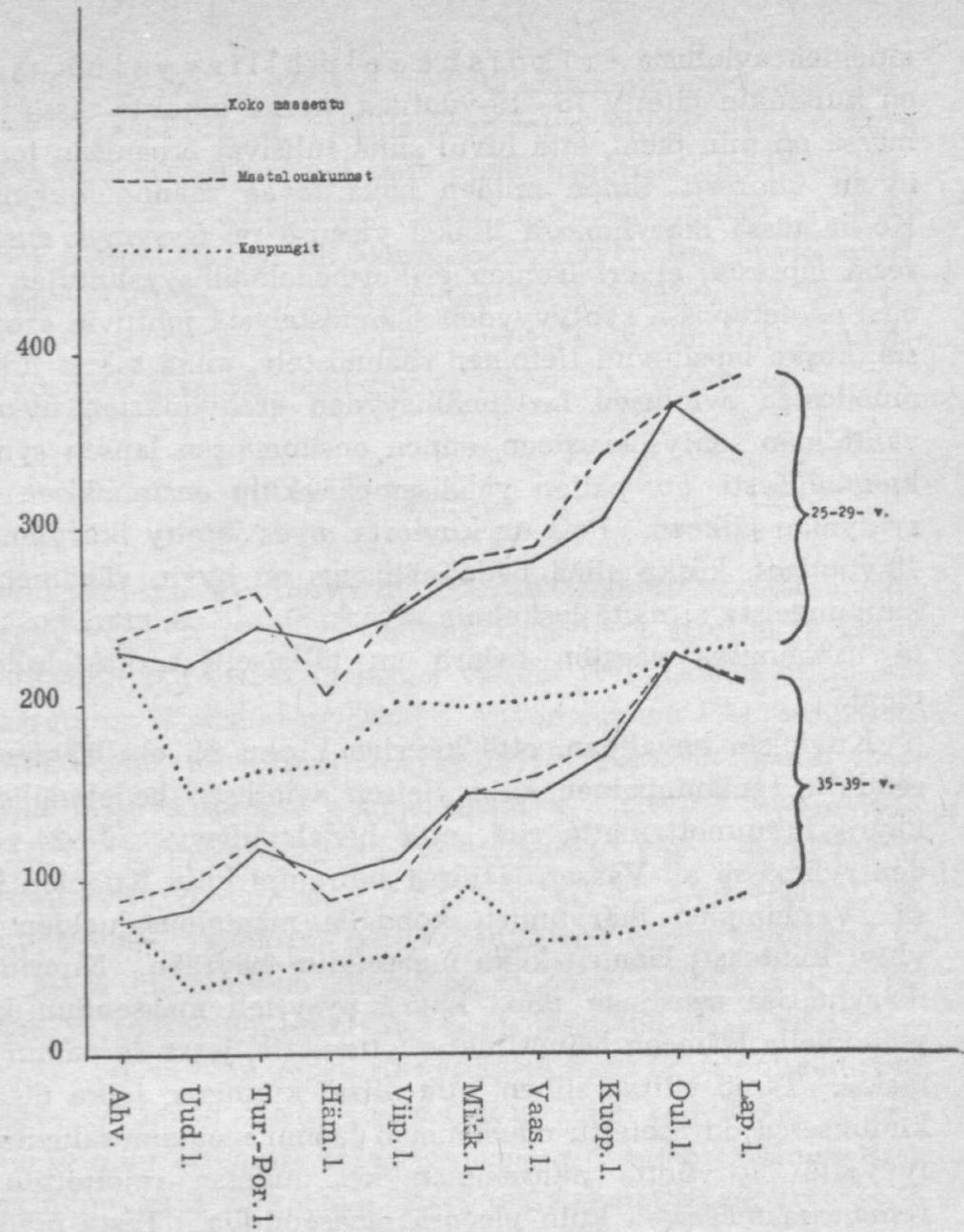

Kuvio 3 B. Ikäluokkien $25-29$ v. ja $35-39$ v. aviolliset erikoishedelmällisyysluvut vv. $1938-39$.

sinki, Turku, Tampere ja Viipuri sekä pienet kaupungit Naantali, Uusikaupunki, Hämeenlinna ja Tammisaari, joissa kaikissa aviollinen hedelmällisyys oli pieni, osoittivat myös vähäistä uusiutumiskykyä.

Taulukossa 3 sekä kuvioissa 3 A-B on vertailtu toisiinsa eri 
alueiden aviollisia erikoishedelmällisy ys $1 \mathrm{ukuja}$. Pois on kuitenkin jätetty 15-19-vuotiaat, koska aineisto tässä ikäryhmässä on niin pieni, että luvut siinä tulisivat eroamaan toisistaan hyvin suuresti ilman mitään havaittavaa säännönmukaisuutta. Koska tässä ikäryhmässä lisäksi yleensä on kysymys ensimmäisestä lapsesta, ei eri läänien erikoishedelmällisyyslukujen välillä olisi odotettavissa syntyvyyden säännöstelystä johtuvia eroavuuksia, koska lapsiluvun tietoinen säännöstely, mikä tekijä ilmeisesti muodostaa aviollisen hedelmällisyyden eroavuuksien olennaisen välittömän selitysperusteen, ennen ensimmäisen lapsen syntymää luonnollisesti on paljon vähäisempää kuin ensimmäisen lapsen syntymän jälkeen. Pois on kuviosta myös jätetty ikäryhmä 4549-vuotiaat, koska siinä hedelmällisyys on hyvin vähäinen. Eri kaupungeista ei näitä laskelmia myöskään ole esitetty, koska niistä useimmissa väestön määrä on tällaiselle tarkastelulle liian pieni.

Kuvioista havaitaan, että käyrien kulku oli eri läänien maaseudulla samantapainen kuin yleisen aviollișen hedelmällisyyden käyrä lukuunottamatta sitä, että hedelmällisyys 20-24-vuotiaiden ryhmässä oli Vaasan läänissä suurempi kuin Kuopion läänissä. Vanhimpien ikäryhmien kohdalla maatalousalueiden käyrä yhtyi kiinteästi läänien koko maaseudun käyrään. Nuorimmissa ikäryhmissä sensijaan tämä käyrä pysytteli maaseudun käyrän yläpuolella Hämeen lääniä lukuunottamatta, jossa se painui alemmaksi. Tämä viittaa siihen, että niissä kunnissa, jotka tässä tutkimuksessa on asetettu edustamaan läänin maatalousalueita, syntyvyyttä 30 vuotta nuorempien keskuudessa rajoitettiin suuremmassa määrässä kuin yleensä maaseudulla. Tästä myös johtuvat pienet luvut, joita Hämeen läänin maatalouskunnat kautta koko tämän tutkimuksen ovat osoittaneet. Edellä jo monesti mainituista laskentateknillisistä syistä ei maatalouskuntien käyrää kuitenkaan voida pitää täysin tarkkana. Niinpä se »heilahteleekin» enemmän kuin maaseudun käyrä.

Myös kaupunkien käyrä oli kaikissa ikäryhmissä suunnilleen samanlainen kuin vastaava aviollisen hedelmällisyyden käyrä lukuunottamatta sitä, että se Lapin läänin kohdalla pysytteli kor- 
keammalla kuin Oulun läänissä. Niissä lääneissä, joissa aviollinen hedelmällisyys oli suuri, oli maaseudun ja kaupunkien välinen ero tässä suhteessa suurempi kuin eteläisemmissä lääneissä. Ahvenanmaata lukuunottamatta, jossa Maarianhaminan ansiosta aviollinen hedelmällisyys oli »kaupunkien» ryhmässä hyvin suuri, havaitaan aviollisen hedelmällisyyden tietyssä ikäryhmässä maaseudulla olleen suunnilleen yhtä suuren kuin lähinnä nuoremmassa viisivuotisikäryhmässä saman läänin kaupungeissa.

\section{Loppukatsaus.}

Edellä esitetyn selvittelyn mukaan maaseudun väestön uusiutumiskyky vuosina 1938-39 vaihteli noin 1.8:n (Oulun ja Lapin lääni) ja 0.9:n (Uudenmaan lääni) välillä. Viimeksimainitun läänin maaseudun lisäksi ei myöskään Ahvenanmaan läänin maaseutu osoittautunut uusiutumiskykyiseksi, ja Hämeen läänin maaseutu jäi tässä suhteessa epämääräiseksi. Yleensä uusiutumiskyky kasvoi siirryttäessä itään ja pohjoiseen päin. Kaupunkien uusiutumiskyky vaihteli $\mathrm{n}$. 0.5:n (Helsinki) ja 1.1:n (Kemi) välillä luvun vain viimeksimainitun kaupungin osalta kohotessa yli 1.0:n. Myös kaupunkien ryhmässä ilmeni - mutta paljon lievempänä ja epäsäännöllisempänä kuin maaseudun - edellämainittu uusiutumiskyvyn kasvu siirryttäessä itään ja pohjoiseen päin. Kuitenkin oli maan eteläosassakin muutamia kaupunkeja, joissa uusiutumiskyky oli suuri (Maarianhamina, Rauma). Muistettava kuitenkin on, että tarkastelu tässä on suoritettu edellytyksellä, että kuolevuussuhteet toisaalta maaseudulla ja toisaalta kaupungeissa kautta koko maan olisivat olleet samanlaiset. Saatuja sotaa edeltäneitä viimeisiä rauhanvuosia koskevia tuloksia ei myöskään voi yleistää myöhempiä vuosia silmälläpitäen, koska aviollinen hedelmällisyys ja syntyneisyys viimeisiä sotia välittömästi seuranneina vuosina ovat suuresti nousseet. Niinpä Helsingin väestö osoittautui vuonna 1946 poikkeuksellisesti jopa uusiutumiskykyiseksikin (nettouusiutumisluku 1.001).13 Maan kaupungeissa keskimäärin (nettouusiutumisluku 1946 1.148) suhteelli- 
nen nousu ei ollut yhtä suuri, ja vielä pienempi se oli keskimäärin maaseudulla, jossa nettouusiutumisluku saavutti huippunsa (1.541) vasta seuraavana vuonna 1947.14

Uusiutumiskyvyn eroavuudet maaseudulla saivat pääasiallisen selityksensä aviollisen hedelmällisyyden eroavuuksista, kun sensijaan kaupungeissa oli havaittavissa myös siviilisäätyryhmityksen vaikutus. Eroavuudet aviollisessa hedelmällisyydessä maan eri osissa olivat suunnilleen samantapaiset eri ikäryhmissä nuorinta ikäryhmää (15-19-v.) lukuunottamatta, jossa säännönmukaisuutta ei ollut havaittavissa.

\section{Lähdeviitteitä ja huomautuksia.}

1 Ks. esim. Kuczynski, Robert R., The Balance of Births and Deaths I, New York 1928.

2 Vrt. sama, ss. 25-31, 46-48.

3 HTV (Helsingin kaupungin tilastollinen vuosikirja) 1949, T (taulu) 50.

4 Suomen väestön nettouusiutumislukuia on esitetty vuosikymmeniltä 1881-1890 sekä vuosikymmeniltä $1901-1920$ ja sitä seuraavalta 5-vuotiskaudelta (Kuczynski, mt., s. 51), viisivuotiskaudelta 1931-35 (Modeen, G. ja Fougstedt, Gunnar, Laskelmia Suomen vastaisesta väestönkehityksestä, SVT (Suomen virallinen tilasto) VI 89, s. 31) ja 5-vuotiskaudelta $1936-40$ sekä erikseen vuosilta 1938-1944 (Fougstedt, Gunnar, Nativiteten i Finland under krigsåren, Statsvetenskaplig tidskrift för politik, statistik, ekonomi, Lund 1946, s. 432). Vuoden 1948 niteestä alkaen sisältyy Suomen tilastolliseen vuosikirjaan (STV) vuodesta 1936 lähtien eri vuosilta ja 5-vuotiskaudelta tietoja koko maen kaupunkien (yhtenä ryhmänä) ja maaseudun maassa asuvan väestön netto- ja bruttouusiutumiluvuista sekä myös muiden maiden väestöjen bruttouusiutumisluvuista (STV 1948, T 32 ja 358). Samat luvut selityksin varustettuina sisältyvät myös tilastollisen päätoimiston julkaisemaan tutkimukseen $\gg$ Suomen väestöä, sen uusiutumista ja tulevaa kehitystä koskevia laskelmia (Hypoölä, Jorma-Tunkelo, Aarre-Törnqvist, Leo, mt., Tilastollisia tiedonantoia 38, ss. 25-31). Myös amerikkalainen vảestötieteellinen aikakauslehti Population Index on julkaissut ko. lukuja mm. Suomesta v:sta 1911 alkaen (Population Index 1950, ss. 173-174). Pienempien alueiden uusiutumislaskelmista mainittakoon, että vuosien 1931-1935 kuolleisuuteen ja vuoden 1931 syntyneisyyteen perustuvan Helsingin nettouusiutumisluvun on laskettu olleen 0.381 (Kannisto, Väinö, Helsingin väestötase, Suomalainen Suomi 1941, s. 59). Samojen vuosien kuolleisuuteen ja vuosien 1938-1940 syntyneisyyteen perustuvien nettouusiutumislukujen totesi tämän kirjoittaja 1942-1943 olleen: Tampereella 0.535 , Turussa 0.482 , Vaasassa 0.712 , Oulussa 0.846 , Lahdessa 0.667 , Kuopiossa 0.673 , Kotkassa 0.675 , Jyväskylässä 0.662 ja Joensuussa 0.750 (eri sanomalehdissä julkaistuja laskelmia). Helsingin kaupungin tilastolliseen vuosikirjaan sisältyy vuoden 1949 niteestä alkaen tietoia Helsingin ja koko maan nettouusiutumisluvuista (HTV 1949, T 56). (Lähdeviitteet jatkuvat s. 56.) 


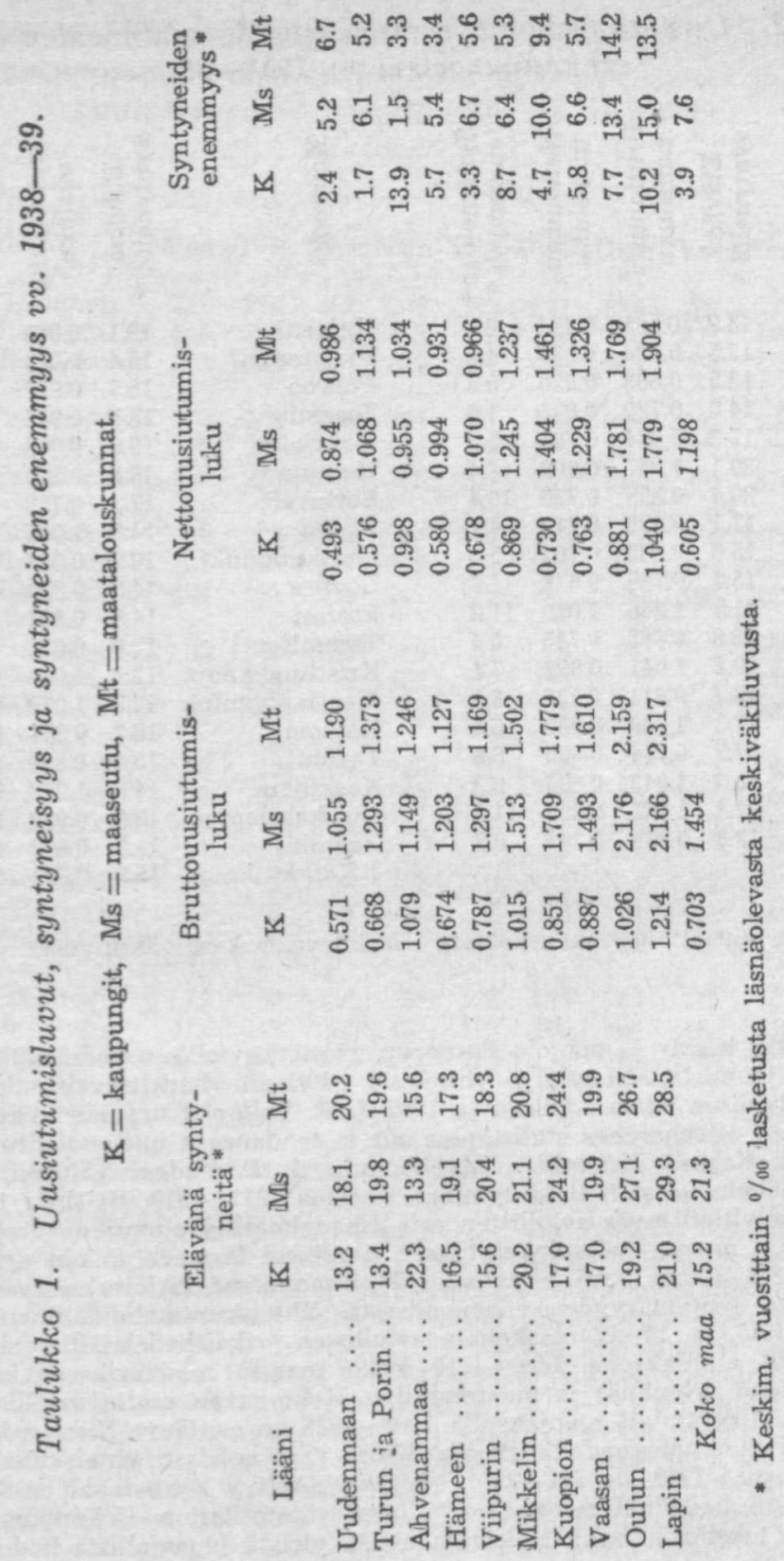


Taulukko 2. Uusiutumisluvut, syntyneisyys ja syntyneiden enemmyys eri kaupungeissa vv. 1938-39.

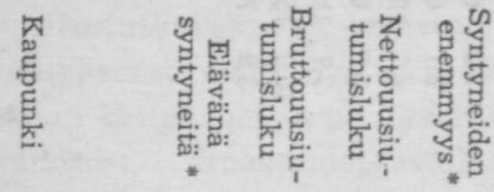

$\begin{array}{llllr}\text { Helsinki } & 13.2 & 0.561 & 0.484 & 2.5 \\ \text { Tampere } & 15.5 & 0.624 & 0.537 & 4.4 \\ \text { Turku } & 12.5 & 0.603 & 0.520 & 0.8 \\ \text { Viipuri } & 14.6 & 0.729 & 0.628 & 1.6 \\ \text { Vaasa } & 17.3 & 0.884 & 0.761 & 5.9 \\ \text { Oulu } & 20.1 & 1.057 & 0.909 & 8.4 \\ \text { Lahti } & 20.4 & 0.855 & 0.739 & 10.4 \\ \text { Kuopio } & 17.1 & 0.839 & 0.719 & 4.7 \\ \text { Kotka } & 15.6 & 0.889 & 0.765 & 5.3 \\ \text { Pori } & 15.7 & 0.786 & 0.678 & 4.0 \\ \text { Kemi } & 21.7 & 1.266 & 1.086 & 11.2 \\ \text { Lappeenranta } & 18.8 & 0.868 & 0.745 & 6.4 \\ \text { Mikkeli } & 20.2 & 1.041 & 0.892 & 7.4 \\ \text { Hämeenlinna } & 13.7 & 0.611 & 0.525 & 3.1 \\ \text { Rauma } & 17.3 & 1.046 & 0.902 & 6.4 \\ \text { Jyväskylä } & 17.9 & 0.774 & 0.665 & 6.6 \\ \text { Kokkola } & 19.9 & 1.043 & 0.896 & 9.3 \\ \text { Savonlinna } & 21.4 & 1.045 & 0.893 & 11.8 \\ \text { Hanko } & 12.8 & 0.865 & 0.747 & 0.3\end{array}$

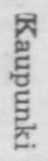

Kajaani
Pietarsaari
Porvoo
Joensuu
Käkisalmi
Hamina
Sortavala
Raahe
Uusikaupunki
Laviisa
Iisalmi
Tammisaari
Kristiinankaup.
Naarianhamina
Heinola
Tornio
Kaskinen
Uusikaarlepyy
Naantali
$\quad$ Kaikki kaup.
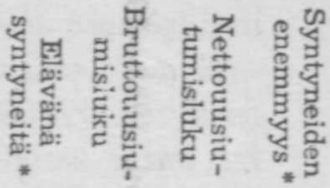

\section{1}

15.4

16.5

18.3

\subsection{9}

0.832

19.6

0.924

0.927

0.794

0.798

0.809

$\begin{array}{ll}16.8 & 0.899\end{array}$

0.945

0.828

0.773

$17.3 \quad 0.753$

14.61 .005

0.646

0.862

10.20 .624

$14.8 \quad 0.870$

0.538

0.750

0.705

$14.8 \quad 0.821$

12.50 .636

0.547

0.872

12.81 .015

$\begin{array}{ll}22.3 & 1.079\end{array}$

$16.7 \quad 0.851$

0.928

0.730

0.759

$15.4 \quad 0.890$

$14.0 \quad 1.028$

0.884

0.823

$12.2 \quad 0.956$

$11.3 \quad 0.670$

0.577

0.605

* Keskim, vuosittain \%o lasketusta läsnäolevasta keskiväkiluvusta.

5 Länsi-, keski- ja pohjois-Euroopan väestön aviollisen hedelmällisyyden alenemistaipumusta, sen syitä ja yhteyksiä erityisesti sharkitsevaisuuden hengen» yleistymisen kanssa valaisi jo $1886 \mathrm{~J}$. V. Tallqvist uraauurtavassa väitöskirjassaan $\gg$ Recherches statistiques sur la tendance a une moindre fécondité des mariages», Helsinki). Myöhemmin A. E. Tudeer väitöskirjassaan (Hämeen läänin väestön lisääntyminen vuosina 1811-1910, Helsinki 1914, ss. 223-233) selvitteli myös aviollisten erikoishedelmällisyyslukujen kehitystä ja riippuvuutta muista väestönkehityksen ilmiöistä Hämeen läänin eri osissa vuodesta 1831 alkaen sekä esitti eräässä pienemmässä kirjoituksessaan (Viimeaikaisesta syntyneisyyden vähenemisestä, Yhteiskuntataloudellinen Aikakauskirja 1915, ss. $15-25$ ) laskelmia aviollisten erikoishedelmällisyyslukujen alenemisesta ajanjaksona 1880-1910 koko maassa sekä erikseen kaupungeissa (yhtenä ryhmänä) ja maaseudulla. Koko maan osalta aviolliset erikoishedelmällisyysluvut ajanjaksolta 1866-1925 on esittänyt Kuczynski (mt., s. 37) sekä tältä vuosisadalta Heikki Waris (Suomalaisen yhteiskunnan rakenne, Helsinki 1948, ss. 227-230). Lisäksi sisältyy koko maan osalta tietoja yleisestä hedelmällisyydestä virallisen väestötilaston sVäestönmuutokset s sarjan tekstiosiin sekä Helsingin osalta yleistä ja aviollista hedelmälli- 
Taulukko 3. Eri 5-vuotisikäruhmiin kuuluvien aviovaimojen keskimäärin vuosittain sunnuttämien lasten luku 1000 vastravarn ikäryhmään kuuluvaa aviovaimoa kohden vv. 1938-39.

Aidin

Alue

Lääni

ikä, v.

Uud. T-P. Ahv. Häm. Viip. Mikk. Kuop. Vaas. Oul. Lap. maa

$20-2$

Kaupungit
Maaseutu
Maatal.kunn.

$\begin{array}{llll}217 & 274 & 352 & 249\end{array}$

$309 \quad 331$

$\begin{array}{llllll}343 & 397 & 328 & 393 & 377 & 384\end{array}$

401

$422 \quad 343$

310

374

428

284

287

336

347

261

25-29

Kaunungit

150

$1 \% 2 \quad 233$

Maasentu

222

Maatal.kunn.

253

$244 \quad 230$

263

$30-34$

Kaupungit

$\begin{array}{rr}86 & 93 \\ 131 & 165\end{array}$

237

165

235

$201 \quad 198$

451

435. 395

Maseutu

131

Maatal.kunn.

144

18

$$
\text { 35-39 }
$$

Kaupungit
M=asevitu
Maatal kunn

$\begin{array}{ll}38 & 47\end{array}$

163

205

$\begin{array}{lll}250 & 275\end{array}$

252

282

$205 \quad 202$

$303 \quad 281$

225

232

174

272

(

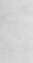

$40-44$

$\begin{array}{ll}\text { Kaupungit } & 12 \\ \text { Maaseutu } & 36\end{array}$

Maatal.kunn.

$\begin{array}{ll}83 & 118\end{array}$

134

$\begin{array}{ll}95 & 106\end{array}$

138

$341 \quad 289$

340

385

13014

$\begin{array}{lll}159 & 161 & 205\end{array}$

1.15

$\begin{array}{lll}118 & 138 & 122\end{array}$

$\begin{array}{lll}197 & 280 & 258\end{array}$

99

187

$\begin{array}{llllll}80 & 52 & 57 & 99 & 66 & 64\end{array}$

$\begin{array}{rrrrrr}86 & 52 & 57 & 99 & f 6 & f 4 \\ 86 & 102 & 112 & 150 & 171 & 147\end{array}$

297

on

210

212

136

19

\section{9}

20

55

30

50

23

$\begin{array}{ll}36 & 31 \\ 72 & 90 \\ 69 & 93\end{array}$

$\begin{array}{ll}36 & 31 \\ 72 & 90 \\ 69 & 93\end{array}$

$\begin{array}{ll}55 & 30 \\ 53 & 33\end{array}$

546
46

$\begin{array}{rrrr}27 & 40 & 51 & 20 \\ 75 & 145 & 120 & 70 \\ 77 & 143 & 124 & \end{array}$

45-49

$\begin{array}{llll}\text { Kaupungit } & 1 & 1 & - \\ \text { Maaseutu } & 5 & 6 & 6 \\ \text { Maatal.kunn. } & 6 & 6 & 5\end{array}$

2
6
5

2
7
6

$\begin{array}{rrrrrr}5 & 4 & 1 & 1 & 8 & 2 \\ 8 & 12 & 12 & 17 & 14 & 9 \\ 8 & 11 & 11 & 16 & 15 & \end{array}$

$\begin{array}{llrrr}15-49 & \text { Kaupungit } & 77 & 89 & 154 \\ \text { (aviolli- Maaseutu } & 122 & 149 & 125 \\ \text { nen ylei- Maatal.kunn, } & 144 & 155 & 130 \\ \text { nen hedel- } \\ \text { mällisyys) }\end{array}$

$\begin{array}{rrrr}95 & 102 & 126 & 109 \\ 137 & 150 & 169 & 194 \\ 122 & 137 & 171 & 202\end{array}$

113
182
195

$137 \quad 133$

$\begin{array}{lll}247 & 238 & 168\end{array}$

mällisyys)

syyttä koskevia tietoja kaupungin tilastolliseen vuosikirjaan. Helsingin kaupungin yleisen aviollisen hedelmällisyyden kehitystä vuodesta 1886 lähtien sekä aviollisten erikoishedelmällisyyslukujen kehitystä kaupungin eri seurakunnissa tarkasteli aikoinaan Edvard Gylling (Syntyneisyydestä ja väestön lisääntymisestä Helsingissä, Helsinki 1915). Hänen tutkimustaan ovat jatkaneet Otto Bruun (En àterblick på befolkningsutvecklingen i Helsingfors, Ekonomiska Samfundets tidskrift, Ny serie, h. 27, ss. 1-17) sekä uutta metodia noudattaen, avioliittojen lapsilukua selvittäen, Karl-Erik Forsberg (Fruktsamheten i äktenskap, ingångna i Helsingfors åren 1926, 1929 och 1932, Ek. Semf. tidskr., Ny serie, h. 69, ss. 64-88). Avioliittojen lapsiluvusta kerättiin tietoja jo vuonna 192010 suurimmassa kaupungissa suoritetussa todellisessa väestölaskennassa, ja saatettiin siten valaista tätä rajoitettua väestö- 
Taulukko 4. Elävänä syntyneitä aviolapsia keskimäärin vuosittain 1000:a 15-49-vuotista aviovaimoa kohden eri kaupungeissa vv. $1938-39$.

\begin{tabular}{|c|c|c|}
\hline Helsinki $\ldots \ldots \ldots \ldots \quad 77$ & Hämeenlinna $\quad \ldots .89$ & Raahe \\
\hline Tampere ........ 90 & Rauma $\ldots \ldots \ldots 136$ & Uusikaupunki \\
\hline Turku $\ldots \ldots \ldots \ldots .81$ & Jyväskylä ...... 98 & Laviisa ......... 100 \\
\hline Viipuri & Kokkola ......... 129 & Iisalmi \\
\hline Vaasa & Savonlinna & Tammisaari \\
\hline Oulu & Hanko & Kristiinankaupunki 107 \\
\hline ....... 110 & Kajaani ... & Maarianhamina $\ldots 154$ \\
\hline Kuopio ......... 108 & Pietarsaari & Heinola ......... 114 \\
\hline Kotka $\ldots \ldots \ldots \ldots 110$ & Porvoo ... & Tornio $\ldots \ldots \ldots \ldots 142$ \\
\hline$\ldots \ldots \ldots 103$ & Joensuu . . & Kaskinen $\ldots \ldots \ldots 116$ \\
\hline ........ 133 & Käkisalmi ........ 116 & Uusikaarlepyy $\ldots 150$ \\
\hline uappeenranta $\ldots . .11$ & Hamina & Naantali $\ldots \ldots \ldots \quad 79$ \\
\hline Mikkeli & Sortavala . & Kaikki kaupungit \\
\hline
\end{tabular}

ryhmää monenlaisten näkökohtien mukaan (Avioliittojen hedelmällisyys, SVT VI 69, Helsinki 1930). Lapsilukua eri yhteiskuntaryhmissä Jokioisten kunnassa on tutkinut Vilho $A$. Pesola (Näkökohtia väestökysymyksestämme, Valvoja 1946, ss. 203-212) ia virallisen väestötilaston pohjalla valaissut $>$ Tilastomies; (Missä kansamme nuori polvi kasvaa?, Suomalainen Suomi 1945, ss. 281-283). Martti Muilu on selvitellyt aviollisen hedelmällisyyden kehitystä sotavuosina (Kaupunkien ja maaseudun osuus sotavuosiemme syntyneisyyteen, Suom. Suomi 1947, ss. 9-12) sekä aviollisen hedelmällisyyden eroavuutta toisaalta teollisuuskeskuksissa ja toisaalta maatalousalueilla vuosina 1939-41 ja 1942-45 (Eräiden teollisuuskeskustemme väestön hedelmällisyydestä, Suom. Suomi 1948, ss. 276-278).

6 Maaseudun asunto-olot vuonna 1937, SVT XXXII (Sosiaalisia erikoistutkimuksia) 16 , ss. $1^{*}-6^{*}$ ).

7 SVT VI 95 , ss. $56-79 ; 96$, ss. $4-23,32-33$. - Tilastollisen päätoimiston vuoden 1938 väestönmuutosten työtaulut: syntyneet äidin iän mukaan.

8 Tilastollisen päätoimiston vuoden 1940 kymmenvuotistilaston työtaulut: väestö siviilisäädyn ja iän mukaan. - HTV 1944 - 45, T 36 .

9 SVT VI 91 , ss. $21-26$; 93 , ss. 24-29; 98: 1, T I. - HTV 1949, T 36. Kemin kaupungin osalta on vuosien 1938-1939 keskiväkiluku kuitenkin täytynyt arvioida vuoden 1939 keskiväkiluvun perusteella, koska kaupungin asukasluku vuoden 1938 alussa alueliitoksen johdosta suuresti kasvoi.

10 SVT VI 100, T 14; A 101, T 5, 13 ja 15.

11 HTV 1949, T 50 ja 56.

12 Vastaava luku kaupungeissa keskimäärin oli $14.6 \%$.

13 HTV 1949, T 56.

14 STV 1949, T 29. 